\title{
The Utilization of Post-Mining Through Reclamation Program Based on Indonesian Regulation
}

\author{
Wasis Susetio \\ Faculty of Law \\ University of Esa Unggul \\ Jakarta, Indonesia \\ wsusetio07@yahoo.com
}

\begin{abstract}
This study examines the utilization of post-mining though reclamation program according to Indonesian regulation. It deals with whether the existed regulation is in line with Law No. 4 of 2009 on Minerals and Coal and the Minister of Energy and Mineral Resources No. 7 year 2014 on the Implementation of Reclamation and Post Mining Activities of Mineral and Coal Mining Business and effective post-mining coping efforts, particularly abandoned holes that may lead to dangerous areas. Empirical study is the type included in this study by conducting an observation toward the utilization of natural resources, particularly post-mining in the field and reviewing the Law made on it. Data were analyzed and presented qualitatively. Results show that Ministerial Regulation number 7 year 2014 is deemed to not contradict with Government Regulation number 78 year 2010 as long as it is followed by clear explanation and strict condition as well as requirements to carry out reclamation for another designation, such as tourism. It needed further detail requirements for any parties who want to involve in reclaiming a former mining to be travel destination, or other facilities.
\end{abstract}

Keywords-utilization; post mining; reclamation; Indonesian regulation

\section{INTRODUCTION}

Non-renewable natural resources such as oil and other mining materials if extracted should be in careful planning to realize a sustainable national development process [1]. Among the sustainability of the development is the realization of an independent community after the closure/termination of the mine. Economic activity still runs after the termination of the mine, and does not make a Ghost Town.

One of the activities in utilizing natural resources is mining activity of mining which until now is one of the largest contributor's foreign exchange sector of the country. However, if mining activities is not implemented properly, it can have a significant negative impact on the environment in the form of [2]: 1) decreased land productivity; (2) occurrence of erosion and sedimentation; (3) the occurrence of ground motion/landslide; (4) disturbance to flora and fauna; (5) microclimate change; (6) social problems.

The main problem facing post-mining is the abundance of open pit areas into gaping holes that are unused, even harmful to the surrounding environment. Therefore, since Law No. 11 of 1967 about Basic Provisions on Mining, the miners are required to reclaim. However, the reclamation of ex-mining land is not only an attempt to improve the post-mining environment condition, in order to produce a good ecosystem environment and strive to be better than the initial hue, carried out by considering the potential of minerals that are still left behind.

However, since the issuance of various regulations to require reclamation activities, mine land cover remains ineffective, even miners tend to ignore because of the provision that it seems to give substitution obligations to cover the excavated land by simply paying the reclamation money, as regulated in Government Regulation Number 78 of 2010 on Reclamation and Post-mining (PP No. 78 of 2010).

According to The Ministry of Energy and Mineral Resources (ESDM) that estimates that the number of holders of Mining Business License (IUP) in the next year will only be 3,000 companies. Recorded number of existing IUP reached 9,721 companies [3]

Director General of Minerals and Coal Ministry of Energy and Mineral Resources, Bambang Gatot, said that of the total existing IUP only 6,335 IUPs in 2017 are Clear and Clean $(\mathrm{CnC})$. Meanwhile, about 3,286 other IUPs are still under reconciliation by the Governor. It can be imagined that if one of Work Mining Area will have 5 holes it may produce more than 48.500 holes throughout the country, it was excluded the age of holes which had been abandoned long time ago in varies regions (www.esdm.go.id)

Based on PP no. 78 of 2010 clearly mandates the company must close the mine (reclamation) hole no later than 30 calendar days after no mining activities. But it was not implemented, in particular, with regard to coal mining systems in Indonesia are generally implemented by means of open pit mining by excavation methods back (back filling methods) tailored to backup conditions and quality of existing coal geological structure. Application of open mining methods adjusted for the calculation of coal reserves with layers slope, while the back filling method serves as an attempt to minimizing the extent of open land due to mining activities, therefore hoarding activities along with active mine movement running [4].

The open mine is more often done because of the displacement of the soil and overburden is cheaper to finance 
when compared with underground tunnel excavations. An open mine is a the type of quarry where the excavation material is deep in the ground and occurs on a coal mine and can occur on any excavation activity and construction and there are also special impacts on mining activities coal [4]. Use of heavy equipment on activities Coal mining is also known to result in the presence of holes large excavations with a depth of 3 to 4 meters [5].

To overcome such problem, finally the government through the ministry of Energy and Mineral Resources issued Regulation of Minister of Energy and Mineral Resources No. 7 of 2014 on the Implementation of Reclamation and PostMining on Mineral and Coal Mining Business Activities. In this Ministerial Regulation, IUP Holders may not fulfill their obligation to close the excavated pits with the stockpiling in accordance with the provisions of Government Regulation Number 78 of 2010. One of them is to make the former mine become a tourist area.

However, many circles who actually doubt the issuance of Ministerial Regulation of ESDM Number 7 of 2014. According to some observer's point of view state that Ministry Regulation of ESDM No. 7 Year 2014 is problematic. The regulation encourages the omission by the government to companies that do not close the ex-mine hole. The government should impose tough sanctions on companies that do not reclaim.

The environmental impacts of mining may be decrease in soil productivity, soil compaction, erosion and sedimentation, movement soil and landslides, disruption to flora and fauna, disruption to security and population health and micro-climate change. Also water acid mine is known as a major environmental problem in mining coal. Pollution of water both surface water and groundwater can also be occurred due to coal mining [4].

As a result of soil compaction causes in the dry season the soil becomes dense and hard. In this heavily textured soil, the absorption of water into the soil takes place slowly because the soil pores are so small, so will be able to increase the rate of surface water flow which has an impact on increasing the rate erosion. The hard and solid soil conditions are very heavy to be processed in a manner does not directly affect the increase in labor needs [4].

This study is to examine whether the Minister of Energy and Mineral Resources Regulation No.7 Year 2014 on Reclamation and Post-Mining Activities on Mineral and Coal Mining Activities is in conformity with Law No. 4 of 2009 on Minerals and Coal and the Minister of Energy and Mineral Resources No. 7 year 2014 on the Implementation of Reclamation and Post Mining Activities of Mineral and Coal Mining Business and effective post-mining coping efforts, particularly abandoned holes that may lead to dangerous areas.

\section{METHOD}

This study belongs to normative type to review the government's regulation on the utilization of natural resources. Empirical study is the type included in this study by conducting an observation toward the utilization of natural resources, particularly post-mining in the field and reviewing the Law made on it. Data were collected from the field where mining are available through observing the condition of the utilization of it. Library study was also conducted to obtain the existed regulation made on the utilization of the mining. Data were analyzed and presented qualitatively.

\section{RESULT AND DISCUSSION}

\section{A. Condition of Post-Mining}

The chemical condition of the former mining area shows the soil fertility, $\mathrm{pH}$ and the presence of nutrients in the soil while low the presence of heavy metal heavy metal due to the solution of metal sulphide. Circumstances nutrients such as low $\mathrm{N}$ and $\mathrm{P}$ elements, acid or alkaline soil reactions is the main problem. Low soil $\mathrm{pH}$ resulted in decline the supply of nutrients such as $\mathrm{N}, \mathrm{P}, \mathrm{K}, \mathrm{Mg}$ and $\mathrm{Ca}$ which are sufficient dangerous to high soil temperatures. Due to high acidity the soil can causes: Damage to absorption system elements $\mathrm{P}, \mathrm{Ca}$, $\mathrm{Mg}$ and $\mathrm{K}$ by plants. The lack of element $\mathrm{P}$ becomes a problem because of the low $\mathrm{P}$ element in the remnants mining, Increasing availability of $\mathrm{Al}, \mathrm{Mn}$ and $\mathrm{Fe}, \mathrm{Cu}, \mathrm{Zn}$ and $\mathrm{Ni}$ [6].

\section{B. Reclamation Program and the Regulation toward Post- Mining}

Based on the article 1 number 26 Law no. 4 of 2009 regarding Mineral and Coal states Reclamation is activities done throughout stages business of mining for organize, restore, and fix it quality environment and ecosystem so that could function back corresponding designation.

Reclamation has been regulated based on previous Law of Mining, Law Number 11 year 1967. In the Law stipulated to minimize the negative impacts of mining activities, Law Number 11 Year 1967 on Basic Provisions on Mining Article 30 states that every holder of mining authority is required to return the land in such a way that it does not pose any danger of disease or other danger, such as through 'reclamation'. Mining companies are also required to restore the former mining areas and have been regulated in various laws and regulations as bellow:

- Article 30 of Law Number 11 Year 1967 concerning Basic Provisions on Mining: In case of completion of mining of excavated material at a work place, the holder of the Mining Concession shall be required to return the land in such a way that it does not pose any danger to the surrounding community.

- Article 46 paragraph (4) and (5) of Government Regulation Number 75 of 2001 concerning Second Amendment to Government Regulation Number 32 Year 1969: Before leaving the former Mining Authority, either due to cancellation or otherwise, the holder of the Mining Authority shall first undertake safeguards against the objects or buildings and the circumstances surrounding the land which may endanger public safety.

This regulation becomes a foothold for improving postmining environment so that the impact of environmental and even social damage can be minimized before UU No. 4 year 
2009 regarding Mineral and Coal (UU Minerba). The technical procedures of mine reclamation to mine closure have also been clearly prepared by the government. The provisions of reclamation shall be regulated in Regulation of the Minister of Energy and Mineral Resources Number 18 Year 2008 regarding Reclamation and Closure of Mining [7].

After UU Minerba, the government issued Government regulation number 78 year 2010 regarding Reclamation and Post Mining. In the considering of regulation states that to implement the provisions of Article 101 of Law Number 4 Year 2009 regarding Mining

Minerals and Coal, it is necessary to stipulate a Government Regulation on Reclamation and Post-mining, meanwhile reference of the government regulation the article 100 and 101 UU Minerba stipulates that (the article 100):

- IUP and IUPK holders are required to provide reclamation and post-mining guarantee funds

- The minister, governor, or regent/mayor in accordance with his or her authority may assign third parties to reclaim and post-mining with the guarantee fund as referred to in paragraph (1)

- The provisions referred to in paragraph (2) shall apply if IUP or IUPK holders do not carry out appropriate reclamation and post-mining with an approved plan.

With regard to the article 100 , we can conclude that there is a guarantee funds and also third party to undertake reclamation funds if the miner ignore or doesn't want to undertake reclamation. Some of such provision effect negative impact to the miner behavior to ignore reclamation program.

Furthermore, there are currently about 9,700 coal mining permits issued by the government. Mining exploitation activities must be openly excavated. Assuming one permit, leaving at least five mined holes, it has been imagined the number of environmental threats, health, and safety of the soul (drowning dangers) ready to emerge. Whereas if one permits leave only five pits, there will be about 48,500 pits. Anyway, five is still a minimum number, so it could be more than that number [8]. In fact, before mining companies obtain mining permits (IUPs) or coal mining concession works (PKP2B), they should include reclamation planning and post-mining activities. They should also include and pay for reclamation guarantees in the form of bank guarantees or deposits or joint accounts.

This reclamation guarantee varies widely, depending on the area of mining and reclamation as it is done. However, many companies do not have reclamation plans and do not pay for reclamation guarantees, but managed to get IUPs [9].

Based on the article 20 sub article 1 and 2 and also article 21 of Government Regulation Number 78 year 2010, states that Holders IUP must carry out reclamation and it must be done within 30 days. But, refer to the article 10 letter d states postmining programs, including: 1. reclamation on ex-mining land and outside mine land; 2 . maintenance of reclamation result; 3 . community development and empowerment; and 4 . monitoring. Furthermore in the article 12 states that further provisions regarding the procedures for the preparation of plans and criteria for post-mining success are regulated with Ministerial Regulation.

By reading the above provision, it could be unclear interpretation to ensure that the ex- mining hole will be heaped or closed, because the definition of reclamation is a kind of open legal policy to recover condition. Government Regulation, or even Law Number 4 year 2009 only stating reclamation as activities carried out throughout stages mining business to organize, restore, and improve the quality of the environment and ecosystem in order to function again accordingly designation. It means that any several options may take for reclaiming to the ex-mining area as long as it can be utilized again.

Under article 12, further provisions concerning reclamation procedures and procedures shall be delegated to the minister to regulate them, including the forms of reclamation and designation.

By the argumentation which based on Law Number 12 year 2011 regarding Making Regulatory Regulations, article 8 paragraph 2 which stipulates the Laws and Regulations, including Ministerial Regulation is acknowledged to exist and has a binding legal force all along ordered by the Laws and Regulations which is higher or formed based on authority.

Therefore, The Ministry of Energy and Mineral Resources issued Ministerial Regulation Number 7 year 2014, then within the article 1 number 3 states Post-mining activities, hereinafter referred to Post-mining, is a planned activity, systematic, and continues after the end of some or all activities mining efforts to restore function natural environment and social functions according to local conditions in all mining areas.

There is specific reasons to restore, either for natural environment or social function, hence it could be deemed that reclamation will not merely an activities to close or heap an exmining hole but also utilize the area to functionalize as stipulated in the article 12 paragraph 4 which states (4) Reclamation Program of Phase of Production Operation as referred to in paragraph (3) letter c may be executed in form of re-vegetation and / or other appropriations. Then in article 5 states that other allocations referred to in paragraph (4) can be: a. residential area; b. tourism; c. water sources; or d. cultivation area.

Furthermore, in the article 12 paragraph 1 states Holder IUP Exploration and IUPK Exploration required compile plan Reclamation stage Operation Production for period time 5 (five) year with details annual.

In Government Regulation Number 78 of 2010 on Reclamation and Post Mining in Article 2 Paragraph (1) contains clauses mandatory to carry out reclamation and postmining, as well as in Article 21. The obligatory clause means that every business actor or holder of IUP Exploration, IUPK Exploitation shall carry out reclamation.

In the legal clause, shall mean must be implemented, and if not implemented then there are sanctions that regulate the act. In the reclamation and post mining there are administrative witnesses. Administrative sanctions in this case are written warnings, suspension of activities, and revocation of permits. 
In the administrative sanctions provided do not eliminate obligations for business holders to carry out reclamation and post mining.

Judging from non-compliance with the policies and legislation, the Minister, Governor, and Mayor / Regent as the Government have the authority to supervise any licenses issued by it or by the government level below it, as Article 71 of Law Number 32 Year 2009 on Environmental Protection and Management.

Avoiding to the sanction effect and with regards to the abandoned hole, we can refer to the Ministerial Regulation Number 7 year 2014, especially article 5 paragraph 4 to reclaim by another designation to be tourism are, although it must obey the rule to carry out term and strict condition, such as re-vegetation

In the article 12 paragraph 6 stipulates that in the implementation activities mining on technical leave hole former mine, then required created plan utilization hole former mine include: a. stabilization slope; b. security hole former mine (void); c. recovery and monitoring quality water and management water in hole former mining (void) in line with designation; and d. maintenance hole former mine (void).

By corresponding with the rule above, it may focus on the re-vegetation program. Re-vegetation is an activity of planting post-mining area with selected plants. Re-vegetation begins with planting cover crops and trees, as well as crop maintenance [4]. Successful Re-vegetation on mining land is determined by many aspects of which are aspects landscape arrangement, fertility of planting media and planting and maintenance plant. Landscape arrangement is closely related to soil conservation and soil conservation water and mine land use plan. Meanwhile deep the fertility of the media is largely determined by the physical, chemical, and biological properties of the soil.

Not only that, technically, former mining water which has been contaminated can be purified by bioremediation of water treatment. In underground mining the environmental damage is generally caused by the waste (tailings) produced in the ore refining process. Both inner and open pit mines cause the release of certain chemical elements such as $\mathrm{Fe}$ and $\mathrm{S}$ from pyrite compounds (Fe2S) to produce acidic drainage (Acid Mine Drainage/Acid Rock Drainage) which can be carried away by the flow of the surface during rain, and into agricultural land on the downstream of the mine, thus causing higher soil moisture. The soil and acidic water of the mine is very acidic with a $\mathrm{pH}$ ranging from 2.5 to 3.5 potentially polluting agricultural land.

Bioremediation is the use of microorganisms to reduce pollutants in the environment. When bioremediation occurs, the enzymes produced by microorganisms modify toxic pollutants by altering the chemical structure of the pollutant, an event called biotransformation. In many cases, biotransformation leads to biodegradation, where toxic pollutants are degraded, their structure becomes uncomplicated, and ultimately becomes a harmless and nontoxic metabolite [10].
Bioremediation is the process of cleaning land pollution by using microorganisms (fungi, bacteria). Bioremediation aims to break down or degrade pollutants into substances that are less toxic or non-toxic (carbon dioxide and water) [11].

Since the 1900s, people have used microorganisms to treat water in waterways. Currently, bioremediation has grown in the treatment of hazardous waste (chemical compounds that are difficult to degrade), which are usually associated with industrial activities. Included in these pollutants include heavy metals, petroleum hydrocarbons, and halogenated organic compounds such as pesticides, herbicides, and others. Many new applications use microorganisms to reduce the pollutants being tested. The current field of bioremediation has been supported by better knowledge of how pollutants can be degraded by microorganisms, identification of new and beneficial types of microbes, and the ability to increase bioremediation through genetic technology. Molecular genetic technology is essential for identifying genes that encode enzymes associated with bioremediation. The characterization of the genes in question can improve our understanding of how microbes modify toxic pollutants to be harmless [10].

Another treatment is Acid Mine Drainage (AMD). It has already many technologies aimed at overcoming the MD. Technology applied both based on chemical and biological principles has not provided results that can overcome AMD as a whole. Techniques based on chemical principles, such as calcification, though costly but the results can only increase the $\mathrm{pH}$ and are temporary. Anoxic lime drain making techniques that combine physical and chemical principles are also very expensive and the results are not encouraging. Bioremediation technique by utilizing sulphide reducing bacteria gives quite encouraging results.

There are still remain many research to rehabilitate and restore the condition of post-mining area, therefore, it is possible and feasible to reclaim the former mining zone to recover, rehabilitate, or restore, including become tourism zone. In fact, in Indonesia, there are some travel destination which was mining holes in the past without anxious to harm or poisonous, such as Bukit Jaddih in Madura, Brown Canyon in Semarang, Lubang Tambang MbahSuro, Sawahlunto, Sumatera Barat, Bukit Jamur, Gresik, and other.

\section{CONCLUSION}

Ministerial Regulation number 7 year 2014 is deemed to not contradict with Government Regulation number 78 year 2010 as long as it is followed by clear explanation and strict condition as well as requirements to carry out reclamation for another designation, such as tourism. It needed further detail requirements for any parties who want to involve in reclaiming a former mining to be travel destination, or other facilities. As the problem solving concept, Government or local government may issue the specific regulation to the detailed description of developing ex mining holes and give a strict condition to be applied as well as sanction for any violation. Besides that, it needed also effective monitoring by not only officer but also participatory community that can also involve maintaining and managing the area of former mining. There is some opportunity to attract investor in reclaiming former mining area to be travel 
destination based on the Ministerial regulation Number 7 year 2014.

\section{ACKNOWLEDGEMENT}

The author would like to thank all the parties who have helped and contributed in the writing of this article, both those who contribute in the form of funding and critical ideas. Hopefully this paper can be useful theoretically and practically for the addition and development of knowledge, especially in the field of legal science.

\section{REFERENCES}

[1] Aji, N. S., Development of Mining and Iron Sand Processing Industry and Its Implication on Regional Economic Resilience (Study in KulonProgo Regency of Special Region of Yogyakarta). National Resilience Journal, Number XX (2) August 2014, 47-58.

[2] Arief, N., Principles of Mine Reclamation.Planning Training Open Mine, Bandung: Unisba, 2004.

[3] M. Rizki, Reklamasi Lahan Tambang Pada Pertambangan Terbuka Dengan Pengelolaan Tanaman Mangga (Mangifera indica L.) https://psdhayati.wordpress.com/2012/11/05/reklamasi-lahan-tambang- pada-pertambangan-terbuka-dengan-pengelolaan-tanaman-manggamangifera-indica-1/) 2012.

[4] Adman, B., Potential Growing Local Tree Types Grow for Recovery of Post Coat Coal Land Area (Case Study at PT SinglurusPratama, East Kalimantan). Thesis of Diponegoro University Graduate Program, Not Published. 2012.

[5] Hasibuan, M. P., The Impact of Mining of Group C Cigarette Materials to the surrounding environment in Deli Serdang Regency. Equality Journal.Vol. 11 No. February 1, 2006.

[6] Kesuma, The Influence of Mining Activities on Building $C$ Free Intake.Thesis of Student Program of Natural Resource Management and Environment (PSL) Graduate School University of North Sumatra (USU). Thesis not published, 2006.

[7] Djajakirana, G., Soil Destruction as Impacts of Agricultural Development .Department of Soil, Faculty of Agriculture: Bogor Agricultural University. Bogor. 2001.

[8] G, Subowo, "Eco Friendly Mining System And Efforts Post-Mining Reclamation To Improve Resource Quality Land and Soil Land ", Land Resources, Vol.5, No.2, pp. 83-94. 2011.

[9] E. Darmayanti, P. I K. Gunawan, A. Alaydrus, eJournal Ilmu Pemerintahan, 2017, 5 (4): 1347-1360 ISSN 2477-2458 (online), ISSN 2477-2631 (cetak),ejournal.ip.fisip-unmul.ac.id, 2017.

[10] Perrow M. R. and A. J. Davy. Handbook of Ecological Restoration. Volume I Principles of Restoration. Cambridge University Press. Cambridge, 2002.

[11] Ginoga, L. N. "Insecticides Pollution on the Three Water Birds Species (Little Black Cormorant, Little Egret and Javan Pond Heron) in RiceField at Sukamandi, Subang, West Java." Media Konservasi 10.12005. 